\title{
7
}

\section{Who foots China's bank restructuring bill?}

\section{Guonan Ma}

International experience suggests that bank restructuring, including resolution of non-performing loans (NPLs) and the associated recapitalisation of banks, is often costly-but it is crucial for the stability and functioning of banking systems. ${ }^{1}$ While effectively stemming the flow of new non-performing loans is necessary for a sustained improvement in the banking system, the importance of dealing with the legacy of such loans on the books of banks or within the system should not be understated: in no small measure, it reveals the political willingness of authorities to confront banking problems. Moreover, non-performing loan resolution is often linked with bank recapitalisation. Therefore, the questions of how bank restructuring should be financed and how the associated potential loss should be allocated among parties involved must not be swept under the carpet.

China's bank restructuring bill might eventually approach 30 per cent of GDP. Losses of this magnitude should not be surprising, given that non-performing loans are believed to have accounted for as much as 40 to 50 per cent of loans outstanding at their peak in the late 1990s (Lardy 1998; Bank for International Settlements 1999). Since then, the Chinese government has taken several major steps to recapitalise its banks and reduce non-performing loans. First and foremost, it has focused on repairing banks' balance sheets, but has also recognised the importance of other reforms. ${ }^{2}$ The question of how such large-scale restructuring will be funded is of great interest.

This chapter aims to shed light on the potential cost of bank restructuring in China, how it will be funded and who will foot the bill. There has been limited 
research to understand these issues systematically. This chapter attempts to fill this gap and is organised as follows. The second section sets out a framework to suggest that there are three possible groups of players who might foot the bill: bank shareholders, bank customers and taxpayers. I also discuss relevant experiences from elsewhere in the world, and argue that predetermined and transparent institutional arrangements for apportioning the cost of financial restructuring work best in the long term. The third section reviews some of the measures taken by the Chinese government since 1998 to repair bank balance sheets, including how they were funded and the probable amounts involved. The fourth section discusses some of the short and long-term implications of how Chinese authorities have apportioned losses among the parties involved. Finally, the fifth section concludes the paper with a few brief remarks.

I have reached three main conclusions in this chapter. First, since the late 1990s, the Chinese government has made substantial efforts to face up to the costly and politically difficult challenges of cleaning up bank balance sheetswhich, in my view, has enhanced the credibility of the overall economic restructuring process in China.

Second, the financing arrangements for China's bank restructuring so far have been elaborate. Taxpayers, shareholders and bank customers have all paid for the restructuring bill, with the Ministry of Finance and the People's Bank of China splitting some 85 per cent between them. Foreign banks and other foreign investors also have helped foot the bill-and in so doing have become an emerging force in the Chinese banking sector.

Third, the ways in which the restructuring task has been funded and losses apportioned could have implications for the prospects of the Chinese banking sector. I believe that, as the restructuring process deepens, a more transparent and rule-based framework for assigning financing responsibilities will be necessary in order to contain moral hazard, improve corporate governance, strengthen central bank credibility and further develop domestic capital markets.

\section{Sharing the bank restructuring bill}

How will the expected large financial cost and the associated losses in the Chinese banking system ultimately have to be recognised and paid for? Experiences from elsewhere in the world suggest that, in general, three possible groups of players can end up paying the bill for bank restructuring: existing and new bank shareholders, bank customers and taxpayers.

First and foremost, existing bank shareholders should normally absorb the first loss. In China, the largest banks are state-owned, so that the government might 
end up absorbing a portion of the losses. Sometimes, outside investors or new shareholders are willing to pay for a portion of restructuring costs because of a troubled bank's franchise value. Bank customers-meaning borrowers and depositors-also share the costs through a relatively wide net interest margin. The government, and ultimately the taxpayer, contribute their share when public funds are injected into the banking sector. This can take a number of forms: direct budget outlays funded by government debt as well as bank operating earnings and tax credits; debt issued by public agencies with full state backing (contingent liabilities); and financing by quasi-public agencies without explicit government guarantees.

Depending on the specific purposes, there could be a number of alternative approaches to gauging the potential costs of restructuring bank balance sheets. On one hand, a broad approach is to include all the resources needed to restore the balance sheets to a reasonably healthy state. On the other, a narrower measure would involve only the realised losses. In between, there could be various ways of defining the costs of bank restructuring. In this chapter, I define the 'bank restructuring bill' as the costs that have been incurred to clean up the bank balance sheets, whether the involved resources have been recovered or not. It includes but is not limited to realised losses.

\section{Bank shareholders: old and new}

It is often useful to distinguish between existing and new bank shareholders. Ideally, existing shareholders' capital should be extinguished first to cover losses. In principle, existing equity shareholders should absorb the loss until their capital is fully written off, before any funding from deposit insurance schemes or the treasury is deployed. If bank losses exceed shareholders' equity, but shareholders are allowed to retain a non-trivial claim on the insolvent bank, moral hazard might become an issue.

Sometimes, investors or new shareholders might pay part of a troubled bank's recapitalisation bill. They are willing to invest in an insolvent bank, through a merger or acquisition or simply by taking an equity stake, at a price above the undercapitalised bank's net asset value. These parties are willing to invest in a troubled bank because they recognise its potential franchise value or because regulatory and other costs associated with market entry are prohibitively high. New shareholders can be domestic or foreign banks, non-bank investors or government agencies (Hawkins and Turner 1999). These investors might help increase ownership diversification and strengthen corporate governance of the banks under restructuring; however, when the government itself becomes the only shareholder of a rescued non-state-owned bank (say, through nationalisation), the issues of future exit and (re-)privatisation must be addressed. 
International experience varies, and the outcomes have been mixed on this score. Equity of existing shareholders was fully wiped out in troubled institutions in the early 1990 s during the banking crises in the United States and Norway, and in the late 1990s in Indonesia in the wake of the East Asian financial crisis. In the United States, the Federal Deposit Insurance Corporation adopted the purchaseand-assumption approach, whereby the purchasing bank took over the assets and liabilities of the failed bank through a bidding process, after shareholder equity was eliminated. In Japan, Korea and Sweden, however, the equity of existing shareholders of insolvent banks was, in some cases, partially written down but not eliminated, even as public capital was injected into the failed banks. In Korea and Thailand, foreign and local banks or non-bank investors were allowed to buy equity in some troubled domestic financial institutions, as in the aftermath of the East Asian financial crisis.

\section{Bank customers}

The second group of agents who might, directly or indirectly, help pay the bill are bank customers, meaning borrowers and depositors. ${ }^{3}$ Bank customers usually bear a portion of bank restructuring costs through interest margins earned by banks: specifically, by paying interest spreads above competitively determined market levels, borrowers and depositors contribute to bank operating profits that, over time, help rebuild bank balance sheets. In addition, captive or underdeveloped capital markets hamper competition among banks by limiting disintermediation, in which borrowers can bypass banks and directly tap the capital and money markets for financing. This is a flow approach to recapitalising troubled banks and often requires regulatory forbearance and accompanying tax incentives.

If, however, the initial capital deficiency is large, it might take many years before banks can be nursed back to health via a flow approach. After the East Asian financial crisis of 1997, Thai authorities granted regulatory forbearance to qualified Thai banks so they could continue operating and generate net cash flows. In China, undercapitalised banks have been earning a spread between the official one-year deposit rate and one-year working capital loan rate of 300 basis points, above the levels likely to be seen in a more deregulated environment. Alternatively, the Chinese government was concerned about possible 'adverseselection' risk, opting to regulate deposit and loan rates before banks returned to reasonable health. If, however, a bank's negative equity is equal to 20 per cent of its assets, it could take many years to fill the hole in its balance sheet through the accumulation of net earnings_-even assuming a wide interest margin, no new non-performing loans and no dividends paid. 
More worryingly, moral hazard can emerge because of forbearance. For example, the Federal Savings and Loan Bank Board in the United States allowed many undercapitalised savings and loans to continue operating for some time, while excessive risk-taking by some weak thrifts aggravated their problems further (White 1991). Also, the US Federal Reserve was thought to have pursued an expansionary monetary policy in the early 1990 s in order to steepen the yield curve, thereby widening net interest margins for banks. Some observers felt that this policy sent a signal that big banks making common lending errors, such as excessively risky loan booking, would be made whole by macroeconomic policy.

\section{Taxpayers}

Three general arguments have been put forward to support the use of public funds to bail out troubled banks. First, if the troubled banks are state-owned, the government has an obligation to repair their balance sheets or at least fund their exit from the market. In China, the big four commercial banks were solely stateowned until the recent foreign equity participation in them and their subsequent listing on stock markets. ${ }^{4}$ Note that these four account for more than half of the total assets of the Chinese banking sector (Table 7.1).

Second, if bank losses are related substantially to past policy lending, the government is implicated directly and needs to take responsibility for cleaning up the banking sector. The government's role in this regard has been cited as a key contributor to China's high level of non-performing loans in the 1990s (Zhou 2004).

Third, with or without an explicit deposit insurance scheme, imposing big losses on a large number of small depositors can lead to even more costly systemic risks and even political crises. Given that bank deposits represent some 80 per cent of

\section{Table 7.1 The big four Chinese banks in the Chinese banking system, 2002-2005 (per cent)}

\begin{tabular}{lcccr}
\hline & 2002 & 2003 & 2004 & 2005 \\
$\begin{array}{l}\text { Their share in the total assets } \\
\text { in the Chinese banking system }\end{array}$ & 60.1 & 58.0 & 53.6 & 52.5 \\
Average non-performing loan ratio & 26.2 & 20.4 & 15.6 & 10.5 \\
\hline
\end{tabular}

Note: end of period. The big four banks are the China Construction Bank, Bank of China, Industrial and Commercial Bank of China and Agricultural Bank of China.

Sources: China Banking Regulatory Commission; Moody's Investors' Service, 2005a. Bank System Outlook for China: reform on track, but more needed, June 2005, Hong Kong; Moody's Investors' Service, 2005b. Reform of China's State Banks: moving beyond IPOs; positive rating actions likely, November 2005, Hong Kong. 
Chinese households' financial wealth, it is understandable that the government would be willing to intervene by injecting public money into the banking system.

Indeed, on all three of these cited grounds, the Chinese government might find it necessary and desirable to use taxpayers' money to fund bank restructuring. These considerations might have outweighed the legitimate concerns of Chinese policymakers about moral hazard, which can be dealt with through complementary reforms and a more transparent process of loss allocation.

Typically, there are three general modes of public funding to restore the health of the banking system. Their relative merits depend on the underlying condition of the banking system, as well as the initial endowments of local institutional arrangements and the market environment.

One is a direct budgetary outlay financed by taxes or government debt. This mode tends to enhance transparency and accountability and is consistent with best practice in corporate governance and capital-market development. Approval for these outlays, however, usually has to take place through a formal and sometimes drawn out legislative process, often with the result that the restructuring process is delayed substantially — especially when political consensus cannot be reached.

Another mode of public funding is non-performing loan resolution and bank recapitalisation through debt issued by quasi-government agencies but with fullfaith government guarantees. Such guarantees are explicit contingent liabilities of the government. This approach is transparent and flexible, but it keeps the true costs of cleaning up the banking sector off the government's balance sheet for a time. It might impede bond-market development by splitting the domestic government debt market (McCauley 2003).

Finally, the financing of bank restructuring can be provided by the central bank or other quasi-government agencies without an explicit government guarantee. This approach is fast and expedient but does not always lend itself to accountability or contribute to capital-market development. It sometimes facilitates a desired early start of bank restructuring but might risk creating moral hazard, thus delaying a clear-cut loss allocation. At its limit, in a central bank's case, it can constrain monetary policy in undesirable ways.

Experiences elsewhere in Asia illustrate the various ways taxpayers' money can be used in bank restructuring. In Japan, the Bank of Japan provided liquidity support, secured lending to the stretched deposit insurance scheme and even injected risk capital into failed banks in the late 1990s (Nakaso 2001). However, except for some unresolved minor losses associated with the Bank of Japan's risk capital provision, Japanese government bonds and guarantees financed mainly the injection of public funds into the banking system. During the East Asian financial 
crisis, the Bank of Korea provided significant liquidity support to the financial system, as well as some limited financing to the Korea Asset Management Corporation (Fung et al. 2004). Such exposure by the Bank of Korea, however, was covered with full-faith government guarantees. Also, the Korean government injected much of the public resources directly into the financial system through funds raised by treasury bonds or officially guaranteed debt issued by other quasipublic agencies.

In the same crisis, Bank Indonesia suffered heavy losses because of its massive liquidity support to many local banks, most of which subsequently failed. The bank underwent prolonged negotiations with the finance ministry over partial settlement of such losses. The Bank of Thailand also incurred significant losses in the East Asian financial crisis from guaranteeing creditors and protecting depositors of failed financial institutions through its wholly owned subsidiary, Financial Institutions Development Fund (Fung et al. 2004). Eight years later, protracted and complicated discussions between the Bank of Thailand and Thai fiscal authorities-and partial funding by the government-still have not fully resolved the central bank's loss.

\section{Towards an institutional framework}

A policy question therefore arises as to how the costs of financial restructuring should be apportioned. The major challenge here is striking the delicate balance between safeguarding systemic financial stability, expediting the much-needed restructuring process and preventing or containing future moral hazard (Hawkins and Turner 1999; White 2004). In my view, a well-defined institutional framework for the cost-sharing process tends to work best for strengthening the banking system in the longer term, for at least the following three reasons (Crockett 1998). Transparency. A well-defined institutional framework for cost sharing enhances transparency and disclosure, and promotes good corporate governance. In particular, transparency ensures the accountability of all players in the banking system, including regulatory authorities, bank shareholders, customers and the banks themselves. Moreover, sufficient and upfront financial commitments can help to minimise the costs of bank restructuring by instilling confidence in the process.

Accountability. Predetermined rules define the obligations of all parties involved and discourage shirking of responsibility, thereby reducing the potential for moral hazard, such as the expectation of bailouts in the future. Indeed, ambiguity of rules regarding apportionment of losses often gives rise to moral hazard and encourages accumulation of past bad debts, leading to even more new nonperforming loans (Tang 2005). 
Efficiency. Clear and ex ante loss-sharing frameworks are more efficient, since they reduce the need for repeated and often protracted ad hoc negotiations, avoid inefficient case-by-case legislative processes and enhance cooperation among different agencies and players in the banking system. Moreover, rule-based financing arrangements tend to be more compatible with and conducive to the development of capital markets. ${ }^{5}$

\section{Recent bank restructuring steps in China}

In practice, how the costs associated with China's financial restructuring are to be apportioned among bank shareholders, customers and taxpayers depends in part on the country's institutional realities, and the underlying condition of its financial system. Since the late 1990s, the Chinese government has taken a number of significant measures to repair bank balance sheets, with a cumulative headline restructuring cost possibly as high as 22 per cent of the newly revised 2005 GDP. ${ }^{6}$ Its restructuring efforts were concentrated initially on the big four banks, which account for more than half of China's banking sector (Table 7.1), but now extend to the rest of the sector and even the troubled securities firms industry. This section summarises the principle measures taken by Chinese authorities since 1998 to strengthen bank balance sheets.

Issuance of RMB270 billion in special government bonds in 1998

In August 1998, the government issued bonds to recapitalise the big four banks. The People's Bank of China first lowered the statutory reserve requirement ratio for the banking sector as a whole from 13 per cent to 9 per cent; the Ministry of Finance then issued RMB270 billion (US $\$ 33$ billion) ${ }^{7}$ in special government bonds. The big four state-owned banks used the liquidity freed up by the lowering of the reserve ratio to purchase the bonds. The government then injected all the bond proceeds as equity into the big four banks (Mo 1999), with the consequence that the capital base of the big four banks more than doubled. As the initial sole owner of the big four banks, the Ministry of Finance thus met the capital call from these banks and explicitly burdened future taxpayers to fund a capital injection.

The first round of non-performing loan transfers

In 1999, the government carved out RMB1.4 trillion (US $\$ 173$ billion, or 20 per cent of the total loan balance at the time) in non-performing loans from the big four banks at par value and transferred them to four state-owned asset-management companies. In return, these companies issued bonds to the four banks and 
assumed some of their liabilities to the People's Bank of China. Effectively, this batch of non-performing loan acquisition was 55 per cent financed by assetmanagement company bonds and 45 per cent by People's Bank of China credit. This move was a double act of non-performing loan removal and bank recapitalisation (Ma and Fung 2002).

However, because of the 'constructive ambiguity' of the Ministry of Finance towards its backing of these bonds, the value of the bonds issued by the assetmanagement companies was initially uncertain. Indeed, there might still be a risk that the big four banks swapped their non-performing loans for asset-management company bonds with uncertain prospects for timely debt service. Disclosure is such that it is not clear if the asset-management companies have made regular interest payments to the big four banks on their bonds, or to the People's Bank of China on the liabilities assumed by the purchasing companies. So far, the four asset-management companies have resolved about half of the acquired nonperforming loans, with a 20 per cent cash recovery rate. This would not suffice, on a collective basis, to cover the interest payments on their bonds issued and the People's Bank of China loans assumed so far.

Therefore, at least for a period, the effective recapitalisation of the big four banks might not be as large as the headline non-performing loan removal would suggest, while the balance sheet of the People's Bank of China has clearly suffered. This is a case of recapitalising banks via injections by the central bank and other public agencies (asset-management companies) without an explicit government guarantee. ${ }^{8}$

US $\$ 60$ billion in capital injections from foreign reserves since 2003

In exchange for equity, the People's Bank of China has hitherto injected US $\$ 60$ billion of capital from its foreign reserves into three of the big four banks since late 2003. To bypass the Chinese central bank law that prohibits the People's Bank from owning any commercial banks, a state-owned investment vehicle called the Central Huijin Investment Corporation Limited (Huijin) was set up in 2003 to receive funding from the People's Bank, and to invest the money into the three commercial banks' equity. So far, Huijin has injected US\$22.5 billion each into the China Construction Bank and the Bank of China and US $\$ 15$ billion into the Industrial and Commercial Bank of China. Presumably, such equity investments form the risk capital of the restructured banks - which means that Huijin has become the largest financial holding company in China. Since funding at the margin can be taken to be interest-bearing People's Bank of China bills, this is a case of financing through debts issued by public agencies without full-faith state backing. ${ }^{9}$ 


\section{Loss recognition by existing bank shareholders}

Until recently, most Chinese banks were wholly state-owned. As the initial sole owner of the four big banks, the Ministry if Finance opted to recognise the loss of all of its equity in the China Construction Bank and the Bank of China (some RMB320 billion) as the counterpart of the loan loss write-offs and increases in provisions. Thus, through Huijin, the People's Bank of China took over these two recapitalised banks and became their controlling shareholder. In this case, the original bank shareholders - that is, China's taxpayers-absorbed the loss.

In contrast, in the case of the Industrial and Commercial Bank of China, the Ministry of Finance wrote down only one-third of its original RMB170 billion equity stake, and retained the rest of its equity claims in order to share equal control of the restructured Industrial and Commercial Bank of China with Huijin. However, a massive RMB246 billion of the Industrial and Commercial Bank of China's remaining loan losses has been parked in a special-purpose receivable account at the bank that yields interest to the bank and is reportedly funded by future dividends (supposedly accruing to the Ministry of Finance as a 50 per cent equity owner) and possibly additional tax credits. ${ }^{10}$ Therefore, this is a real mixed bag: shareholders and therefore taxpayers recognise some of the loss instantly and some in instalments. Moreover, the latter arrangement smacks of regulatory forbearance granted by authorities to themselves. Whether the restructuring bill takes the form of receivables or outright write-off and provision of risk capital, taxpayers will eventually have to pick up the tab.

Additional non-performing loan transfers

Since 2004, the People's Bank of China's balance sheet has been tapped twice to fund transfers of doubtful loans at the recapitalised China Construction Bank, the Bank of China and the Industrial and Commercial Bank of China onto the books of the asset-management companies. The total book value of loans transferred has amounted to some RMB780 billion (US $\$ 96$ billion). In 2004, the People's Bank of China bought the first batch of RMB320 billion in doubtful loans from the China Construction Bank and the Bank of China (as well as from the Bank of Communications: see below) for half their book value and then auctioned them to the asset-management companies for 30 to 40 cents on the dollar. ${ }^{11}$ Presumably, the ministry wrote off its equity in the China Construction Bank and the Bank of China as well as giving up the 2003-04 net profits of the two banks to help fund the 50 per cent loss of the RMB320 billion non-performing loan transfer as well as to raise provisions. In 2005, the People's Bank of China bought another RMB460 
billion in doubtful loans from the Industrial and Commercial Bank of China at par value and auctioned them to the asset-management companies for an average of 26 cents on the dollar.

In these two non-performing loan transactions, the People's Bank of China appeared to have made an outright loss, from the differences between the acquisition and auction prices of the doubtful loans involved, of nearly RMB400 billion (US $\$ 50$ billion)—or some 20 times the bank's own reported capital. Furthermore, the People's Bank of China's balance sheet has additional exposure to the assetmanagement companies because it again provided the credit to finance their two non-performing loan acquisitions, as in the 1999 transactions. ${ }^{13}$ In essence, the People's Bank of China has been decapitalised to finance bank recapitalisation, all without a government guarantee, at least on the public record.

\section{Other domestic recapitalisation moves}

In June 2004, the Bank of Communications, the fifth largest bank in China, was recapitalised to the tune of RMB35 billion (US $\$ 4$ billion), after a large portion of its non-performing loans were purchased by the People's Bank of China at 50 per cent of the book value (see the above discussion). The Ministry of Finance and other existing bank shareholders wrote down some of their equity and contributed new capital of RMB7 billion; Huijin invested RMB3 billion (reportedly funded by interest-bearing People's Bank of China bills); the National Social Security Fund chipped in RMB10 billion in return for an equity stake; and HSBC Holdings paid RMB15 billion for a 19.9 per cent stake, a premium of some 40 per cent of the valuation for the Ministry of Finance and Huijin equity investment (see Table 7.2). This recapitalisation exercise was a hybrid one financed by funds from the government and public agencies and existing shareholders, as well as domestic and foreign investors.

There have been several other cases since the late 1990s of new shareholders putting equity capital into the Chinese banking sector. Two more recent examples are listed here. In May 2004, three large non-financial state-owned companies, as founding shareholders of the China Construction Bank, invested RMB8 billion in the newly restructured bank to become its founding shareholders. In addition to its aforementioned equity investment in the Bank of Communications, the National Social Security Fund made an equity investment of RMB10 billion in the newly restructured Bank of China at 1.17 times its 2004 book price and RMB18 billion in the newly restructured Industrial and Commercial Bank of China at about 1.2 times the 2005 book value. 


\section{Table 7.2 Announced direct foreign investment in Chinese banks, 2002- 2006}

\begin{tabular}{|c|c|c|c|}
\hline \multicolumn{4}{|c|}{$\begin{array}{c}\text { Equity investment } \\
\text { US\$ million (per cent) }\end{array}$} \\
\hline \multirow[t]{2}{*}{2002} & Bank of Shanghai & $\mathrm{IFC} / \mathrm{HSBC} / \mathrm{HK}$ & \\
\hline & & Shanghai Commercial Bank & $133(13)$ \\
\hline 2002 & China Everbright Bank & IFC & $19(4.9)$ \\
\hline 2002 & Nanjing City Commercial Bank & IFC & $27(15)$ \\
\hline \multirow[t]{2}{*}{2002} & Shanghai Pudong & & \\
\hline & Development Bank & Citigroup & $73(5)$ \\
\hline 2004 & Industrial Bank & Hang Seng Bank/IFC/GIC & $326(24.9)$ \\
\hline 2004 & Minsheng Bank & IFC/Temasek & $458(6.2)$ \\
\hline 2004 & Shenzhen Development Bank & Newbridge Capital & $150(17.9)$ \\
\hline 2004 & Xian City Commercial Bank & IFC/Bank of Nova Scotia & $6(5)$ \\
\hline \multirow[t]{2}{*}{2004} & Bank of Jinan & Commonwealth & \\
\hline & & Bank of Australia & $17(11)$ \\
\hline 2005 & Bank of Beijing & ING/IFC & $270(24.9)$ \\
\hline \multirow[t]{2}{*}{2005} & Hangzhou City Bank & Commonwealth & \\
\hline & & Bank of Australia & $78(19.9)$ \\
\hline 2005 & Huaxia Joint Stock Bank & Deutsche Bank/Pangaea & $454(20.9)$ \\
\hline 2005 & Bohai Bank & Standard Chartered Bank & $123(19.9)$ \\
\hline 2005 & Bank of Communications & HSBC & $1,750(19.9)$ \\
\hline 2005 & China Construction Bank & Bank of America/Temasek & $3,966(14.1)$ \\
\hline \multirow[t]{2}{*}{2005} & Bank of China & $\begin{array}{l}\text { Royal Bank of Scotland/ } \\
\text { Temasek/UBS/ }\end{array}$ & \\
\hline & & Asian Development Bank & $5,1373(16.2)$ \\
\hline 2005 & Tianjin City Commercial Bank & ANZ Bank & $110(20)$ \\
\hline \multirow[t]{2}{*}{2005} & Industrial and & & \\
\hline & Commercial Bank of China & Goldman Sachs, Allianz, AE & $3,780(8.89)$ \\
\hline \multirow[t]{2}{*}{2006} & Ningbo City Commercial Bank & Overseas-Chinese & \\
\hline & & Banking Corporation & $70.6(12.2)$ \\
\hline Total & & \multicolumn{2}{|c|}{ US\$17 billion (approx.) } \\
\hline
\end{tabular}

Note: The year is the announcement date of the investment. Some announced deals are still pending regulatory approval. The size of investment in the Bank of Communications, the China Construction Bank and the Bank of China are those before the Bank of China's recent initial public offerings (IPOs). The Bohai Bank is a new bank with Standard Chartered as one of its founding shareholders. IFC is the International Finance Corporation, GIC is the Singapore Government Investment Corporation.

Sources: Caijing Magazine, 2004. No. 123; Caijing Magazine, 2005. No. 136; The Asian Wall Street Journal, 2005. 20 June 2005; The Asian Wall Street Journal, 2006. 27 January 2006; The 21st Century Economic Report, 2005. 24 August 2005; Financial News, 2005. 7 September 2005; Financial News, 2005. 9 September 2005; Bank for International Settlements, 1999.

Strengthening the banking system in China: issues and experiences, BIS Policy Papers, No. 7 , October, Basel; China Construction Bank, 2005. Global Offering Prospectus, October, Hong Kong; Bank of China, 2006. Global Offering Prospectus, May, Hong Kong. 


\section{Foreign equity participation}

Foreign investors are footing China's bank restructuring bill to the extent that they are paying a premium for equity stakes in Chinese banks. The official policy has been to encourage foreign strategic investors to become shareholders of Chinese banks and subsequently to list those banks on stock markets. The purpose of this strategy is not just to attract capital, but to diversify ownership, improve corporate governance, promote a credit culture, enhance disclosure and facilitate transfers of knowledge. ${ }^{13}$ Moreover, private or public foreign equity participation provides an exit strategy for the State to recoup its equity investment in recapitalised banks-through sales of equity stakes to foreign investors.

Foreign capital committed to the Chinese banking sector, in the form of either direct or portfolio investment, has been considerable, and the inflow has accelerated since 2002 (Table 7.2 and Appendix 7.2). By early 2006, the total declared foreign direct investment in Chinese banks had reached US $\$ 17$ billion, representing some 15 per cent of the banking sector's core capital, according to some estimates. ${ }^{14}$ Since June 2005, the Bank of Communications, the China Construction Bank and the Bank of China have been listed on the Hong Kong Stock Exchange, raising a combined total of more than US $\$ 20$ billion globally through new share placements. ${ }^{15}$

Cleaning up the rural credit cooperatives and city commercial banks

Since 2001, Chinese policymakers have turned their attention to the other two segments of the banking sector: the second-tier city commercial banks and 34,000 rural credit cooperatives (RCCs). In both segments, local taxpayers, the People's Bank of China and shareholders (existing and new) have footed the bill. The total bill for restructuring the balance sheets of these two sectors could well have exceeded RMB500 billion by late 2005.

To date, the People's Bank of China has issued at least RMB168 billion of its special interest-bearing bills to the RCCs to cover half of their negative equity arising from the recognition of their loan losses-apparently without receiving equity stakes in return. The remainder of the clean-up bill has been met by local governments (through their budgetary accounts or their investment arms) as well as by existing and new shareholders. Financing from the People's Bank of China puts the total estimated restructuring cost of the RCCs at a minimum of RMB336 billion (US $\$ 42$ billion)—and that is just to keep the RCC sector's net worth positive. In addition, to lift the capital adequacy of the RCC sector towards international standards, existing and new RCC shareholders had reportedly injected capital of RMB104 billion for the sector as a whole by mid $2005 .{ }^{16}$ 
The clean-up of the city commercial bank sector has been funded mainly by a mixture of equity dilutions of existing shareholdings and contributions from local fiscal authorities or their investment arms, who have coughed up at least RMB36 billion (US $\$ 5$ billion) so far. ${ }^{17}$ Foreign investors might have also shared the bill by paying a premium to acquire equity stakes in a number of Chinese city commercial banks (Table 7.2).

\section{The changing role of Chinese bank customers}

Bank customers have in effect been contributing to the restructuring bill as well. While liberalisation has led to greater interest-rate flexibility in China, the authorities have continued setting benchmark deposit rate ceilings and minimum lending rates to maintain interest spreads of some 300 basis points. While such spreads might not be the widest in the world, they could shrink considerably if market forces played a more prominent role. In addition, the underdevelopment of China's money and capital markets means that larger depositors cannot seek higher returns on other instruments such as mutual funds, and that sound enterprises cannot lower funding costs by directly tapping the bond markets. In short, disintermediation has taken place on a much smaller scale than otherwise. Until 2004, corporate debt securities represented no more than 2 per cent of the total outside funding of China's non-financial firms (Table 7.3). ${ }^{18}$

If Chinese banks have been able to charge their customers a conservatively estimated 50 basis point excess interest margin in the past five years, I estimate that bank customers would have paid RMB270 billion (US $\$ 33$ billion) towards the bank restructuring bill. Related to this issue is the use of pre-provision net earnings and tax credits to strengthen a bank's capital base. The annual reports of the four big banks suggest that in 2003 and 2004 alone, roughly RMB150 billion (US $\$ 18.5$ billion) was injected into these banks in the form of pre-provision net earnings and tax credits. ${ }^{19}$

\section{Inter-bank swaps of subordinated debt}

Finally, since 2004, subordinated bonds have been issued by Chinese banks as tier-two capital to strengthen their balance sheets. As of late 2005, 12 banks issued at least RMB186 billion of subordinated debt, most of which was taken up by other banks and insurance companies. ${ }^{20}$ Banks have been allowed to buy each other's bonds, with holdings of up to 20 per cent of their own stated core capital permitted. Of course, inter-bank swaps of two-tier capital do not strengthen the banking system as a whole against common adverse shocks. In addition, purchases of such bonds by insurers, as in Japan, pose a risk of contagion 
Table 7.3 Outside fund sources of the non-financial corporate sector, 1998-2004 (RMB billion)

\begin{tabular}{lrrrrr}
\hline & 1998 & 2000 & 2002 & 2003 & 2004 \\
Total sources of & & & & & \\
outside funding & 1,354 & 1,524 & 2,065 & 3,120 & 2,794 \\
Bank loans & 1,015 & 932 & 1,449 & 2,374 & 1,771 \\
Domestic corporate bonds & 4 & 10 & 24 & 37 & 33 \\
\hline
\end{tabular}

Source: The People's Bank of China Quarterly Statistical Bulletin, various issues.

across the financial system. The yields on the subordinated bonds issued by some Chinese state banks were reportedly on a par with or even below those on Ministry of Finance bonds of similar maturities, with little transparency about the pricing mechanism for the subordinated bonds placed publicly or privately, or the distribution of holdings. Taxpayers get little protection from such window dressing (Fukao 2002).

\section{Implications}

In order to gauge the total cost of bank restructuring in China, I have taken into account the financial resources incurred in recognising the past losses as well as those used to beef up the banking sector's capital base to the required levels. Adding up these restructuring exercises in a rather crude manner, the estimated payments towards China's bank restructuring bill to date have approached nearly RMB4 trillion (US\$500 billion)—or 22 per cent of the revised 2005 GDP (Table A7.1). This figure is likely to be an underestimate. Indeed, the headline cost could eventually exceed RMB5 trillion (US $\$ 620$ billion), or more than 28 per cent of GDP, given that the most troubled of the four big state banks has yet to be restructured, the three policy banks will have to be recapitalised and more RCCs and city commercial banks still need to be cleaned up. ${ }^{21}$

The financing arrangements for China's bank restructuring have been complex and wide-ranging. They have included outright Ministry of Finance bonds; tapping the People's Bank of China balance sheet; recent and promised future flows of tax credits and operating earnings; excessive interest margins shouldered by bank customers; capital write-down and calls on existing shareholders; and premiums associated with equity investment by domestic and foreign investors. Thus, taxpayers, shareholders and bank customers have all shared the restructuring bill. The Ministry of Finance and the People's Bank of China together have taken 
care of 85 per cent of the bill, with the rest of the tab being picked up by bank shareholders, investors and customers. Therefore, the consolidated public sector (ultimately taxpayers) is bearing the lion's share of the bill.

While one might debate the relative merits of various ways of funding and apportioning bank losses and the probable size of the restructuring bill, there is little doubt that the Chinese authorities have moved expeditiously in meeting the challenges to the banking system. Nevertheless, the Chinese experience raises a number of important questions. First, what is the likely effect of such restructuring efforts on bank balance sheets? Second, how should one interpret the estimated headline costs of bank restructuring in China? Third, how have the Chinese authorities managed the potential impacts of such large-scale funding exercises on monetary and exchange-rate policies? Finally, what are the long-term implications of these funding approaches? These questions are discussed below.

Balance sheet impact

The short-term impact of these restructuring exercises on the balance sheet of the Chinese banking sector has been marked (Table 7.1). After injections of public and private funds, the balance sheets of most Chinese banks are now in far better shape, with lower non-performing loan levels, enhanced provisions and a stronger capital base across the sector (Moody 2005a, 2005b; Garcia-Herrero et al. 2005). For instance, the recorded aggregate equity capital of China's RCC sector reportedly swung from a sickly -10 per cent at the end of 2002 to almost 6 per cent by June 2005. Similarly, the city commercial bank sector saw its average capital adequacy ratio jump to 5 per cent at the end of 2005 from less than 1.5 per cent just one year earlier. ${ }^{22}$ The recent credit rating upgrades by several international rating agencies of several Chinese banks and the success of their recent IPOs have been an endorsement of such restructuring efforts.

Nevertheless, it is far from clear to what degree recapitalisation measures have strengthened the banking system. Particularly troubling was the ambiguous status of the asset-management company bonds until recently and the incestuous interbank swaps of subordinated debt. Moreover, some in the media claim that public capital taken from the foreign reserves should be principal-guaranteed. Such media opinions would raise doubts about whether such equity should be treated as core risk capital absorbing real shocks, or simply as a vase borrowed for decoration only. If such equity capital investments by the State are counted as forming genuine core risk capital at all, they should, by definition, be subject to downside as well as upside risks. 
There have also been some concerns that, without other complementary reforms, such injections of public financial resources into the banking sector might give rise to moral hazard, which, in turn, would lead to new non-performing loans in the system and repeated state bailouts. While the risk of moral hazard clearly exists and needs to be taken seriously, my view is that the best approach is not to play down but to face up to the potential size of the bank restructuring bill. In fact, by not fully recognising past loan losses and recapitalisation needs, the risk of moral hazard is likely to be accentuated, not mitigated. ${ }^{23}$

\section{Headline restructuring costs}

The final bank restructuring bill might differ from the simple headline number, in part because of two factors: the continuing capital injection, non-performing loan transfers and use of tax credits and bank earnings flows to strengthen bank balance sheets; and possible gains/losses on new equity investment by the government in the restructured banks. Therefore, the size of the eventual total bill could remain uncertain for an extended period.

The first factor is straightforward, mainly because all segments of China's banking sector have not been fully restructured and it is no easy task to discount various timed flows to a common point in time. For example, in the case of future financial flows to fund bank restructuring, the State reportedly has promised the Industrial and Commercial Bank of China and city commercial banks additional tax credits and the use of future retained earnings to rebuild their balance sheets.

The realised gains or losses from Huijin's equity investment and the premium paid by new shareholders might influence not only the headline bill, but how it is apportioned. It is therefore interesting to consider the valuation effects of subsequent private and public equity transactions. For instance, the Bank of America and the Royal Bank of Scotland bought 14 per cent and 16 per cent, respectively, of Huijin's stakes in the China Construction Bank and the Bank of China. I estimate that relative to the original valuation of the initial investment in 2003, Huijin realised a capital gain of nearly RMB10 billion (US $\$ 1.2$ billion) from selling down its China Construction Bank and Bank of China stakes in these two private equity deals (Table 7.2 ).

However, this headline realised capital gain for Huijin could be offset partially by the appreciation of the renminbi since the July 2005 policy change. Moreover, one needs to take into account the rest of the packages, including options, lockups or promises of net asset values above the acquisition prices (China Construction Bank 2005; Bank of China 2006). In the case of the China Construction 
Bank private equity deal, the Bank of America received a call option to increase its stake up to 19.9 per cent, with an expiration date in 2011 and an elaborate strike price structure. The value of such a call option could be significant. By contrast, in the Bank of China private equity transaction, the Royal Bank of Scotland did not receive call options, but secured some downside protection for a limited period. Thus, the realised gains or losses related to Huijin's equity investment might not be known until these options expire or are eliminated and exercised.

Impact on monetary and exchange-rate policy

Chinese policymakers have tried hard to contain possible undesired interference and spillage between these large-scale bank-restructuring exercises, on the one hand, and monetary and exchange-rate policy objectives on the other. Using the central bank balance sheet to fund a big part of bank restructuring has indeed posed some challenges to monetary policy. To avoid injecting excessive liquidity into the banking system within a relatively short period, for example, the People's Bank of China has imposed requirements that its special bills issued to the RCCs and to fund the non-performing loan transactions during 2004-05 will not be transferable or used as collateral for a minimum period of two to three years. The RMB270 billion special government bonds issued in 1998 were also not transferable. Moreover, to cope with the intensified appreciation pressure on the renminbi since 2003, the three recapitalised banks are not allowed to convert their received foreign currency-denominated capital into renminbi for a vesting period of about three years. Therefore, the new bank capital might fluctuate in renminbi terms along with a more flexible exchange rate.

Two questions arise in relation to exchange-rate risks. First, what might the currency composition of bank capital look like? It differs from one bank to another. Whereas the core equity capital of the Industrial and Commercial Bank of China is likely to be denominated half in local currency and half in US dollars, almost the entire tier-one capital of the Bank of China and the China Construction Bank might be denominated in a currency other than renminbi. Indeed, while the Bank of China's core capital was a mix of US dollars and gold (Bank of China 2006), the China Construction Bank's would be mostly US dollar-denominated. This in turns raises the question of the optimal relationship between the currency compositions of a bank's equity and its assets (Fukao 1991).

Second, with a three-year vesting period preventing conversion of US dollars into renminbi, how might these recapitalised banks hedge their exchange-rate risks? In early 2005, Huijin issued currency options to the three recapitalised big banks to hedge, fully or partially, the US dollar portions of their capital. The banks 
paid premiums to acquire the options to sell US dollars against renminbi at strike prices around the prevailing exchange rate of RMB8.277 per US\$ before the July 2005 policy change for a period of up to three years. ${ }^{24}$ Effectively, Huijin and the three recapitalised banks share the foreign-exchange risks through these option arrangements.

Nevertheless, bank restructuring might still have some unintended repercussions, complicating monetary and exchange-rate policymaking. For instance, with an improved capital base, some of the newly listed Chinese banks have been increasingly motivated to lend. But if, in response, the People's Bank of China raised interest rates, capital inflows might pick up further, putting additional appreciation pressure on the renminbi. Another way to tighten monetary conditions, in light of strong external surpluses, could be currency appreciation. Nevertheless, with a big portion of the bank equity denominated in foreign currency, as well as the big net dollar exposures for many Chinese banks, the scope for Chinese policymakers to manoeuvre in the short term, especially at a time of dressing up the balance sheets of banks for their initial overseas listings, could be limited. Thus, without effective foreign-exchange regulations and capital controls, Chinese policymakers might find it quite challenging to juggle the three difficult tasks of bank restructuring, monetary stability and orderly policy shift towards greater currency flexibility. ${ }^{25}$

\section{Longer-term implications}

Four longer-term issues arise from the recent funding practices of China's bank restructuring. First, until the well-defined rules governing loss apportionment emerge and Huijin becomes more transparent, Chinese taxpayers might consider the funding arrangements murky. Lack of ex ante and ex post transparency about the financing of bank restructuring is not conducive to good corporate governance and could lead to moral hazard. To address the stock and flow issues facing the Chinese banking sector, accountability is key-and that needs to start with a set of welldefined rules stipulating financing responsibilities. Also, accountability would influence the level of loss given default in the Chinese banking sector.

Second, some of the ways to fund bank restructuring in China might not be conducive to debt-market development. Keeping bank interest margins high could have been one reason for the underdevelopment of China's bond and money markets. More developed debt markets, while possibly compressing bank interest margins for a while, would benefit the banking sector and economy in the long term. This is because a deeper and broader capital market would encourage banks to rely less on balance-sheet expansion and more on fee income-producing activities and 
enhance the resilience of the financial system (Gyntelberg et al. 2005). In addition, fragmented and often non-tradable debt issued by multiple agencies in financing the bank restructuring process tends to depress debt-market liquidity generally (McCauley 2003). Instead, unifying different issues by various agencies would help improve secondary-market liquidity and promote bond-market development.

Third, specific concerns have also arisen about the heavy use of the central bank balance sheet to fund bank restructuring in China (Ma and Fung 2002). Although taxpayers have footed some 85 per cent of China's restructuring bill, many conventional measures of government debt levels in China have not risen as much. This is possible, in my view, mainly because of the unusual expansion of the central bank balance sheet as well as other quasi-public agency debts not explicitly backed by the government. Between the end of 2001 and the end of 2005, the size of the People's Bank of China's balance sheet more than doubledwith the estimated central bank financing of the country's bank restructuring now representing at least 15 per cent of the entire balance sheet.

In essence, the People's Bank of China is being de-capitalised to the benefit of the banks. Excessive use of the central bank to fund such quasi-fiscal burdens could damage its balance sheet. This could be the result of either a mismatch between liquid liabilities and illiquid assets or the loss of budgetary autonomy (in the event that the central bank's cash flows become negative), or both. And such problems could hinder the long-term institutional development of the central bank in several respects.

- Given the potential conflict of interest between financing needs and monetary objectives, the credibility of a central bank's monetary policy could be compromised.

- Market confidence in the capacity of a central bank to act as a lender of last resort could be eroded over time.

- A large overhang of illiquid and often non-negotiable assets on the balance sheet of the central bank might retard the development of money and bond markets, limit the choices of monetary policy instruments and weaken transmission of monetary policy.

Fourth and finally, the recent pick-up in foreign equity participation in Chinese banks raises the question of how open China's domestic banking market is and how this will affect the sector's outlook. By some measures, such as the scale of foreign banks' local renminbi banking business, the Chinese domestic banking 
market remains arguably one of the most closed major emerging banking markets in the world.

On the other hand, despite the official ceilings on foreign ownership, substantial foreign direct investment and portfolio investment in domestic banks suggest that the Chinese banking sector is opening up. While the prevailing official ceilings on foreign ownership in a Chinese bank are 20 per cent for a single foreign investor and 25 per cent for all foreign investors combined, these restrictions appear to apply only to non-listed banks. For instance, according to my estimates, after their recent IPOs, the effective foreign ownership of the Bank of Communications might have approached 30 per cent, while those of the China Construction Bank and the Bank of China could have already exceeded 25 per cent. This trend of increased foreign equity participation might have an important bearing on the landscape of China's banking market in the long term. In a way, the Chinese banking sector might not be as closed as other measures suggest.

\section{Concluding remarks}

Since 1998, the Chinese government has stepped up the pace of cleaning up the balance sheets of the banking sector, confronting the sizeable restructuring task that might have cost as much as 22 per cent of GDP to date. Funding arrangements have been elaborate, with bank shareholders, bank customers and taxpayers all having shared China's overall financial restructuring cost. Taxpayers have footed most of it, often with little explicit recognition of this fact in official government debt totals. A significant portion of the funding burden could have fallen on the People's Bank of China, as seigniorage has been capitalised through the rising amounts of interest-bearing People's Bank bills and other liabilities.

While efforts to rebuild banks' balance sheets are not a panacea for all the challenges faced by the Chinese banking sector, lingering concerns about moral hazard are no excuse to shun these important measures. I argue, therefore, for a more transparent framework to apportion financing responsibilities among the parties concerned, since well-defined rules of loss allocation restrain moral hazard and promote accountability and market development. The recent increased foreign direct investment in the Chinese banking sector has not only helped fund the restructuring task, but might alter the sector's landscape in the long term-if the experience of the Chinese manufacturing sector in the past three decades is anything to go by. 


\section{Acknowledgments}

I am grateful to my Bank for International Settlements (BIS) colleagues and to participants in the CEPII seminar 'China's financial system: the links between openness and banking crisis' in September 2005 in Paris and the Asian Economic Panel Meeting in May 2006 in Seoul. I am particularly indebted to Robert McCauley, Wing Thye Woo and Rikuichi Nikawa. Any remaining errors are mine. The views expressed in this paper are those of the author and are not necessarily the views of the BIS.

\section{Notes}

1 See, among others, Sheng 1996; Dziobek and Pazarbasioglu 1997; and Hawkins and Turner 1999.

2 Such reforms might include strengthening corporate governance, improving risk management, building up regulatory capacities, fostering a credit culture, liberalising markets and imposing more binding financial disciplines on state-owned companies.

3 Depending on seniority, bank customers could include other bank creditors generally. In a broader sense, fellow banks can also be bank customers contributing to the bill, say, via some deposit insurance scheme that shares the cost of deposit insurance across the banking industry.

4 After the recent foreign equity participation and stock market listings, the big four banks might no longer be appropriately called 'state-owned banks'. Perhaps a more precise name for them would be 'state-controlled banks'. This paper uses 'state-owned banks' and 'state-controlled banks' interchangeably.

5 Ex ante and rule-based frameworks for loss allocation are not necessarily inconsistent with flexible practical strategies to bank restructuring.

6 The latest census indicates that the size of the Chinese economy might have been underestimated by 17 per cent in 2004 GDP figures. This paper uses the census-based 2005 GDP throughout. Also, the discussion will be limited to balance sheet restructuring exercises during 1998-2006, without discounting them back to the same point in time.

7 In this paper, the exchange rate of the Chinese renminbi is RMB8.1/US $\$ 1$, unless otherwise specified.

8 Lately, the Ministry of Finance has become more forthcoming about its willingness to support the bonds issued by two asset-management companies (Cinda and Orient), in the wake of the initial public offerings of the China Construction Bank and Bank of China on the Hong Kong Stock Exchange in November 2005 and June 2006. It says, '[I]n the event that Cinda is unable to pay any interest on the bond in full, the [ministry] will provide financial support... when necessary, the [ministry] will provide support with respect to Cinda's repayment of the principal of the bond' (China Construction Bank 2005; similarly, Bank of China 2006). Even here, there was no mention of the status of the bonds issued by the other two asset-management companies.

9 There have been reports in the press that Huijin has also made equity investments in some undercapitalised local securities houses. It is not apparent how such investment has been funded. One possibility is that the financial resources came from paid-out dividends accruing 
to Huijin's equity stakes in the three big state banks. Another possibility is that the investment was financed by capital gains realised by the sale of part of Huijin's equity stake in the China Construction Bank to foreign investors. A third possibility is additional equity or debt financing from the People's Bank of China.

10 The main motive for the Ministry of Finance to give up future earnings rather than extinguish all of its equity could be to retain a say in the bank restructuring process.

11 Of the RMB320 billion worth of non-performing loans purchased, it is estimated that RMB166 billion were from the Bank of China, RMB129 from the China Construction Bank and the remaining RMB25 billion from the Bank of Communications. Of the RMB166 billion in the Bank of China non-performing loan transaction, RMB18 billion might have been purchased directly by the People's Bank of China at par value (Bank of China 2006).

12 The credit risk to the People's Bank of China loans in this case would be marginally smaller than in the 1999 case, given that this time, the asset-management companies purchased the non-performing loans at auctioned prices rather than at book value. Nevertheless, the People's Bank of China balance sheet remains exposed to the same debtors (asset-management companies), who might find it a huge challenge to service their 1999 loans without special state support.

13 Listing on overseas stock markets was also intended as one way for the Chinese government to push through bank restructuring without being held hostage to the vagaries of local stock markets, which have been undergoing an overhaul lately.

14 Securities Times, 17 December 2005.

15 I assume that foreign investors foot the bill only to the extent that they pay a premium for their equity stakes in Chinese banks. For instance, HSBC paid a 40 per cent premium to take a 19.9 per cent stake in the Bank of Communications, which was listed at an IPO price of 1.54 times the book value. The Bank of America paid 1.15 times book value for its investment in the China Construction Bank, which was later listed at an IPO price of 1.96 times book value. The Royal Bank of Scotland paid 1.17 times book value to take 9.6 per cent of the Bank of China, which was listed at an IPO price of more than two times book value, while a Goldman Sacksled consortium paid 1.22 times book price for a minority stake in the Industrial and Commercial bank of China. Newbridge Capital paid 2.38 times book price to be the largest shareholder in Shenzhen Development Bank.

16 The Financial News, 20 October 2005.

17 The 21st Century Economic Report, 11 August 2005.

18 The situation has, however, been changing since May 2005 when the short-term corporate commercial paper was first introduced in the inter-bank market. It has been priced at less than 3 per cent, compared with the prevailing official one-year best lending rate of more than 5 per cent. To partially compensate the commercial banks, the regulators have limited the principal commercial paper underwriters mainly to these banks so that they can earn as much as 40 basis points of the commercial paper underwriting fees and charge primary rates at 60 basis points above the prevailing yields in the secondary market.

19 However, the operating profits taken to clean up the bank balance sheet might include the extra bank earnings due from captive bank customers.

20 Caijing Magazine, 3 October 2005.

21 Reportedly, the Agriculture Bank of China might require RMB700 billion to restore its balance sheet to health, while the tab for Guangdong Development Bank could run as high as RMB50 billion. I estimate that the city commercial bank sector might need additional injections of some RMB150 billion to clean up the balance sheets or fund their exit, while the restructuring bill for 


\section{The Turning Point in China's Economic Development}

the three state policy banks might reach RMB250 billion.

22 China Securities News, 7 September 2005 and 6 June 2006; China Banking Regulatory Commission.

23 See also Tang 2005. Concerns about moral hazard are real, as evidenced in a number of recent large-scale scandals and fraud at some of the newly restructured banks. Complementary reforms comprise not only those within the banking sector but others in the general economy, such as creditor rights, legal enforcement and the broader reforms of state-owned companies (Xiao 2005).

24 The China Construction Bank bought options to sell dollars to fully cover the US $\$ 22.5$ billion foreign exchange capital injection from Huijin. The Bank of China bought options to cover only US $\$ 18$ billion of the US\$22.5 billion capital injection received from Huijin. The Industrial and Commercial Bank of China's option agreement with Huijin covers US\$12 billion of the US $\$ 15$ billion capital injection received from Huijin. The Southern Weekend Magazine, 19 April 2005; China Money, August 2005, No. 46.

25 Ma and McCauley 2006 discuss the question of whether China's capital controls still bind in the context of monetary independence and onshore/offshore renminbi yield gaps. 


\section{Appendix Table A7.1 Estimating the cost of China's bank restructuring,} by early 2006

\begin{tabular}{|c|c|c|}
\hline No. & Estimation & RMB billion \\
\hline 1 & The RMB270 billion of special government bonds is straightforward. & 270 \\
\hline 2 & $\begin{array}{l}\text { A } 20 \text { per cent net cash recovery ratio of the RMB1.4 trillion } \\
\text { non-performing loan transfer in } 1999 \text { should result in a loss }\end{array}$ & \\
\hline & of 80 per cent, or RMB1.12 trillion. & 1,120 \\
\hline 3 & $\begin{array}{l}\text { US } \$ 60 \text { billion foreign exchange capital injection is worth RMB496 } \\
\text { billion at the strike price of RMB8.27/US } \$ 1 \text {. }\end{array}$ & 496 \\
\hline 4 & $\begin{array}{l}\text { The Ministry of Finance wrote off its equity of RMB320 billion in } \\
\text { the China Construction Bank and the Bank of China, and RMB50 } \\
\text { billion in the Industrial and Commercial Bank of China. A loan loss of } \\
\text { RMB246 is shelved under an Industrial and Commercial Bank of }\end{array}$ & \\
\hline & China receivable account to be funded by the ministry in instalments. & 616 \\
\hline 5 & $\begin{array}{l}\text { The People's Bank of China bore the RMB } 400 \text { billion loss related to } \\
\text { the carving out of the doubtful loans at the China Construction Bank, } \\
\text { the Bank of China and the Industrial and Commercial Bank of China }\end{array}$ & \\
\hline & in 2004 and 2005. & 400 \\
\hline 6 & $\begin{array}{l}\text { RMB35 billion recapitalisation of the Bank of Communications in } 2004 \\
\text { (net of HSBC investment of RMB14.6 billion). Three big state } \\
\text { companies invested another RMB8 billion in the bank as its founding } \\
\text { shareholders. SSF invested RMB18 billion in the Bank of China and } \\
\text { the Industrial and Commercial Bank of China. }\end{array}$ & 46 \\
\hline 7 & $\begin{array}{l}\text { Foreign investors took equity stakes or purchased new shares at } \\
\text { a premium through private equity (strategic investment) and public } \\
\text { equity (stock listing) investment transactions. The combined premium } \\
\text { is conservatively estimated at RMB } 60 \text { billion. }\end{array}$ & 60 \\
\hline 8 & $\begin{array}{l}\text { RMB } 440 \text { billion for recapitalisation and non-performing loan resolution } \\
\text { related to the RCCs and RMB36 billion for city commercial banks. }\end{array}$ & 476 \\
\hline 9 & $\begin{array}{l}\text { RMB270 billion spent by bank customers in the past five years, and } \\
\text { RMB150 billion in pre-provision net earnings based on forbearance in } \\
2003 \text { and 2004. It is assumed that there is an overlap of RMB } 70 \text { billion }\end{array}$ & \\
\hline & between these two items. & 350 \\
\hline 10 & Low-yielding bank subordinated debt (assuming free lunch). & 0 \\
\hline Total & & 3,843 \\
\hline
\end{tabular}

Note: This table serves to provide only a rough estimate of the bank-restructuring bill during 1998-2006. Often, the disclosed information is such that the reported numbers do not lend themselves to easy addition. Simple addition of the listed items in this table might suffer from potential problems of incompleteness, inconsistency, overlapping, double counting and discounting. For instance, there could be some overlapping and related double counting between (1) and (4). Inconsistency could arise between (6) and (7). Item (8) could understate while proper discounting of the earlier financing exercises to 2005 could lift my estimate considerably.

Source: author's own estimates. 